UDC 621.9.013:621.914.2

\author{
A. Agic ${ }^{1,2, *}$, M. Eynian², S. Hägglund ${ }^{1}$, J.-E. Ståhl ${ }^{3}$, T. Beno ${ }^{2}$ \\ ${ }^{1}$ Seco Tools, Fagersta, Sweden \\ ${ }^{2}$ Department of Engineering Science, University West, Trollhättan, \\ Sweden \\ ${ }^{3}$ Production and Materials Engineering, Lund University, Lund, \\ Sweden \\ *adnan.agic@secotools.com
}

\title{
Influence of radial depth of cut on entry conditions and dynamics in face milling application
}

The choice of milling cutter geometry and appropriate cutting data for certain milling application is of vital importance for successful machining results. Unfavorable selection of cutting conditions might give rise to high load impacts that cause severe cutting edge damage. Under some circumstances the radial depth of cut in combination with milling cutter geometry might give unfavorable entry conditions $c$ точки зрения сил and vibration amplitudes. This phenomenon is originated from the geometrical features that affect the rise time of the cutting edge engagement into workpiece at different radial depths of cut. As the radial depth of cut is often an important parameter, particularly when machining difficult-to-cut materials, it is important to explore the driving mechanism behind vibrations generation. In this study, acceleration of the workpiece is measured for different radial depths of cut and cutting edge geometries. The influence of the radial depth of cut on the dynamical behavior is evaluated in time and frequency domains. The results for different radial depths of cut and cutting geometries are quantified using the root mean square value of acceleration. The outcome of this research study can be used both for the better cutting data recommendations and improved tool design.

vibration.

Keywords: milling, entry, radial depth, cutting edge, cutting force,

\section{INTRODUCTION}

Dynamics of the milling process is one of the parameters that has significant effect on the tool life. Dynamic characteristics of the machine-toolworkpiece often set the boundaries on the material removal rate. Additionally, the selection of the cutting data in combination with the workpiece material plays an important role in the vibrational behavior of the cutting process. As the milling process is intermittent per definition, the impact loads at the entries and exits of the cutting edges give rise to the transient and forced vibrations that in combination with the self-excited vibrations generate complex vibratory motion of the cutting edge. The dynamics of the cutting process is explored in depth by [1], where the focus has been set on the stability approach and chip wave regeneration effects, meta stability according to [4]. This theory results in certain cutting conditions that ensure stable cutting action. Even the concept of differential pitch cutters originates from the general chatter theory, which is explained in [2]. However, the stable cutting action is still characterized by vibration amplitudes that most frequently

(C) A. AGIC, M. EYNIAN, S. HÄGGLUND, J.-E. STÅHL, T. BENO, 2017 
have negative effect on the cutting tools, as it has been shown in [3]. These amplitudes are strongly reinforced by impact loads originating from the entry and exit of the cutting edges. Another essential source of the vibratory motion of the cutting edge is the chip segmentation, which is explained in great details in [4]. Extensive research work has also been done on the measurements of the cutting forces and vibrations. For the cutting force measurements, stationary dynamometers mounted on the machine table or rotating dynamometers mounted in the spindle are often utilized. These devices give valuable insight into the cutting process but they have in general limited frequency range which brings uncertainty into the cutting force evaluation. A comparison study for chatter detection including cutting force dynamometer, accelerometer, spindle electrical power signal and acoustic emission has been reported in [5]. The results indicate that multi-sensor signal composed of the axial force and the accelerometers gives best accuracy and robustness.

This is extremely important in the intermittent machining when the force buildup process is characterized by very short rise times and high impact loads. In the work presented here, the vibration measurement is carried out with triaxial accelerometer attached to the workpiece. This study analyzes the effect of the entry condition on the vibrations in face milling application as a function of a radial depth of cut. Basically, the rise time for force build-up is, among other, a function of the radial depth of cut. The experimental work is followed by analysis of the measured acceleration in the time and frequency domain. A method using root mean square value, $R M S$, directly computed from the sampled acceleration data from the workpiece vibration is presented. RMS captures the amplitudes of the vibration for different cutting conditions, which in this particular case is a radial depth of cut. The RMS method is applied on the trials with a face milling cutter with one tooth to identify the critical radial depth of cut, i.e., the position that causes highest vibration amplitudes. In addition, the influence of the cutting edge geometry on the total vibrational behavior is also analyzed.

\section{METHODOLOGY}

The cutting tests were conducted in the milling machine MS500 with BT50 tool holder. A number of workpieces from the same batch have been specially prepared to make sure the consistency in the trials. The workpieces have been pre-machined to the identical dimensions and given radial depth of cut to ensure constant arc length of cut during the engagement. Three cutting geometries were run in five different cutting conditions so totally there have been 15 trials. Each trial generated 14 engagements that were used for the analysis. The cutter has been equipped with one tooth. Some additional tests have been done with fully equipped cutter, with 6 inserts and the results from these tests are also commented. A simplified modal analysis of the workpiece and vice was carried out in order to find out the dynamical properties of the system. The sampled acceleration files were analyzed in Mathcad software, there the sampled data have been processed in time and frequency domain.

\section{Cutting test conditions}

The experiments were run at the same cutting conditions except for the radial depth of cut. Assuming that the uncut chip thickness can be expressed as follows:

$$
h_{1}(\theta)=f_{z} \sin \theta,
$$

where $\theta$ is the engagement angle of the cutting insert, the uncut chip thickness at the entry can adopt equal values on the up-milling and down-milling section of the 
cut. The radial depths of cut $\mathrm{B}$ and $\mathrm{E}$ are chosen to get equal chip thickness at the entry and the same is done for the radial depths of cut C and D. This is schematically shown in Fig. 1. Additionally, the full engagement with $100 \%$ radial depth of cut is run as case A. The complete set of the cutting data used in the tests is shown in Table 1 . The situations at the very entry of the cutting edge into the workpiece for the defined radial depths of cut are illustrated in Fig. 2. The arrow shows the feed direction.

A

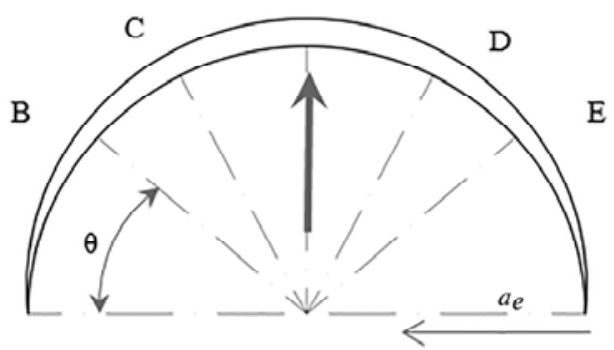

Fig. 1. Chip thickness profile and the entry positions.

Table 1. Cutting data used in the experiments

\begin{tabular}{cccccc}
\hline Radial position & $a_{p}, \mathrm{~mm}$ & $f_{z}, \mathrm{~mm} / \mathrm{t}$ & $v_{c}, \mathrm{~m} / \mathrm{min}$ & $\mathrm{a}_{e}, \mathrm{~mm}$ \\
\hline A & 4.0 & 0.25 & 160 & 80.0 \\
B & 4.0 & 0.25 & 160 & 70.0 \\
C & 4.0 & 0.25 & 160 & 58.15 \\
D & 4.0 & 0.25 & 160 & 21.85 \\
E & 4.0 & 0.25 & 160 & 10.0 \\
\hline
\end{tabular}

\section{Cutting tool geometries}

The milling cutter used in the trials is R220.53-0080-12-6A. Three different cutting geometries, CG1, CG2, and CG3 have been run in the tests. The geometrical description of the cutting geometries is illustrated in Fig. 3 followed by the normalized values in Table 2.

Table 2. Normalized values for cutting geometries

\begin{tabular}{c|c|c|c|c|c}
\hline Cutting geometrie & $\mathrm{V}$ & $\mathrm{V}_{n}$ & $b_{n}$ & $\alpha$ & $E R$ \\
\hline CG1 & 0.5 & 0.5 & 1.0 & 1.0 & 0.8 \\
CG2 & 1.0 & 0.3 & 0.8 & 1.0 & 0.8 \\
CG3 & 0.3 & 1.0 & 1.0 & 1.0 & 1.0 \\
\hline
\end{tabular}

The helix angle of the cutting edges for the cutting geometries CG1 and CG2 are identical while the cutting edge of the CG3 is slightly different. This difference is shown in Fig. 4.

\section{Experimental setup}

The clamping system of the workpiece in the milling machine is shown in Fig. 5. The workpiece material was steel 42CrMo4. The section of the workpiece was $100 \times 100 \mathrm{~mm}$ with length of $300 \mathrm{~mm}$. The overhang of the workpiece from the vice was $125 \mathrm{~mm}$. 


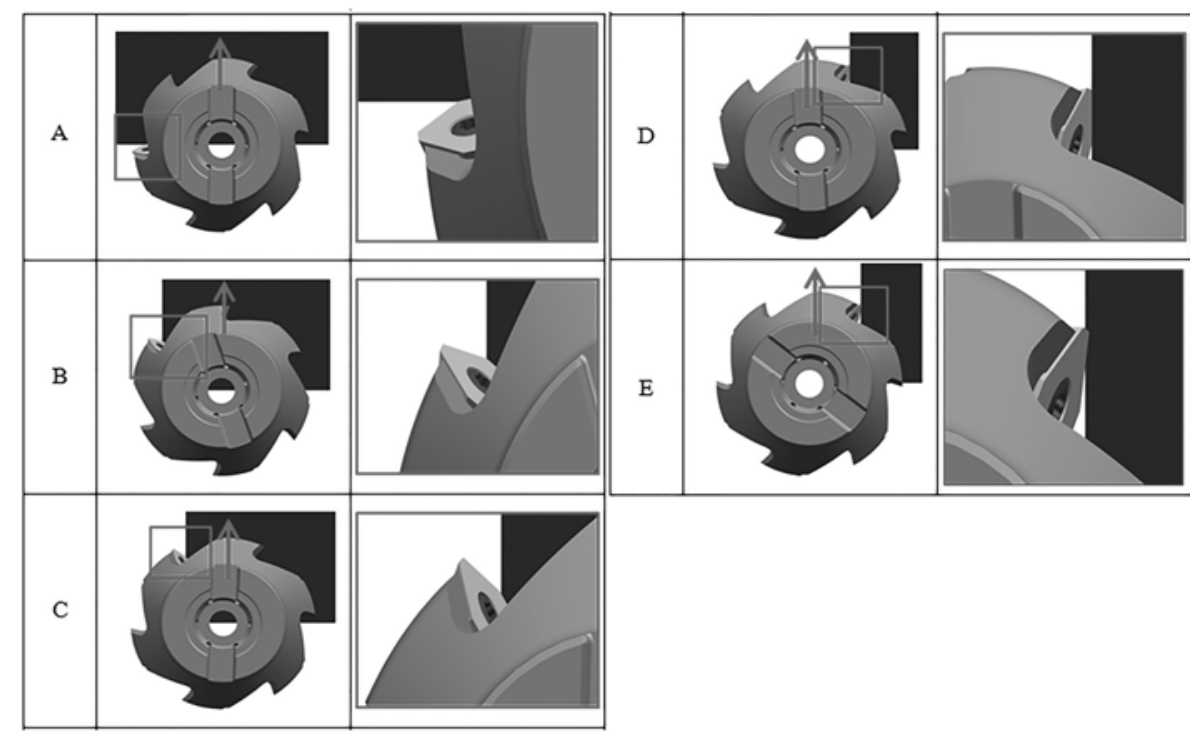

Fig. 2. The positions of the cutting edge at very entry into workpiece for A, B, C, D, and E case.

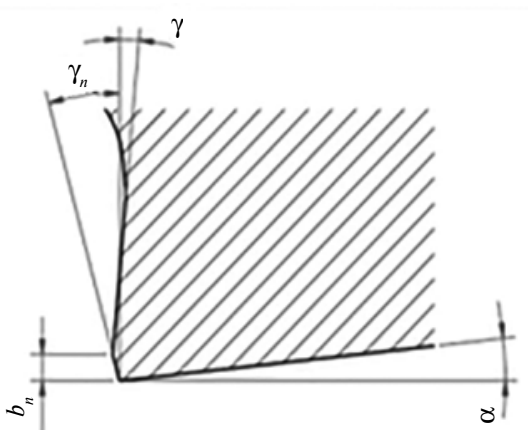

Fig. 3. Cutting edge geometry.

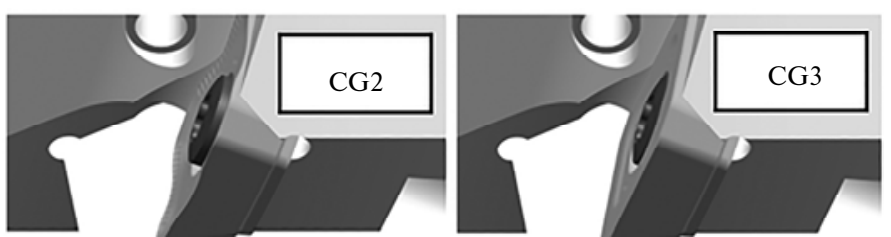

Fig. 4. Cutting edge line for the cutting geometries.

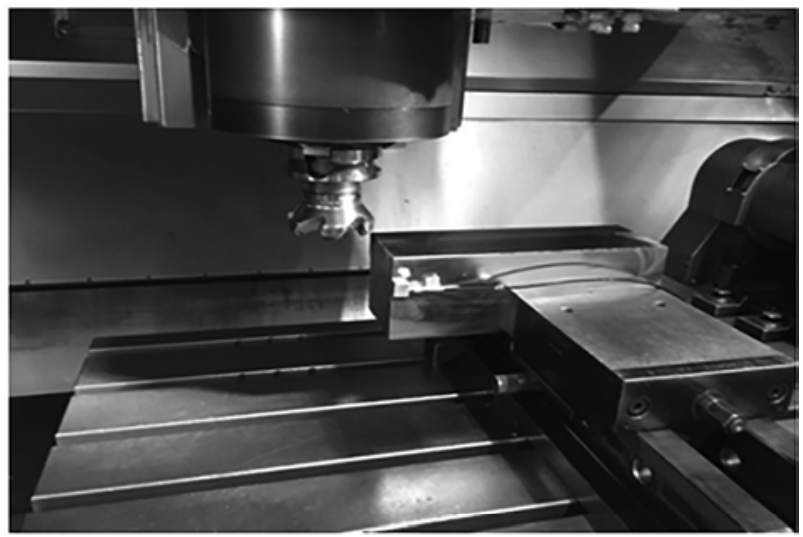

Fig. 5. Clamping of the work piece in the milling machine. 
The triaxial accelerometer of type Dytran 3093B was attached to the very end of the workpiece as shown in Fig. 5. The accelerometer was connected to a USB Single Module Carrier NI 9233. The sampling frequency used in the DAQ system was $25 \mathrm{kHz}$. The time domain acceleration data was sampled and the further analysis was conducted in Mathcad. The dynamic properties of the workpiece during the milling process change as a certain part of the material is removed. The dynamic properties are also very sensitive in terms of the position of the milling cutter in relation to the accelerometer. In order to ensure the same conditions as much as possible, a number of special blanks have been made for the experiments where the cutting took place at the same position in the $X$ axis in relation to the accelerometer for all experiments. The milled blanks are shown in Fig. 6.

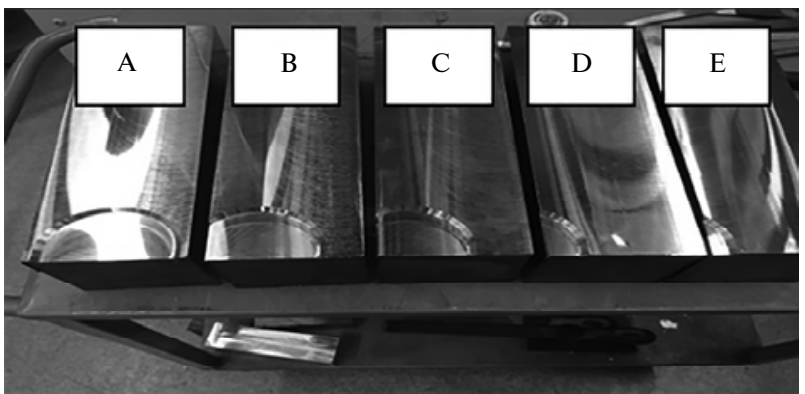

Fig. 6. Milled blanks utilized in the experiments.

\section{Modal analysis}

In order to find out the dynamic properties of the structure consisting of the workpiece, vice and clamping system, a modal analysis of this part of the machine structure has been carried out. The main goal of the modal analysis has been to extract dominant modes in the $X, Y$ and $Z$ directions, while the modal shapes have not been treated. The equipment utilized for the experimental modal analysis was Dytran impact hammer, model 5800B3 and the accelerometer, model 3093B. The hit point on the structure was fixed while the accelerometer was set to 4 different positions as shown in Fig. 7. The measurement points were chosen to capture the relative motion between the parts of the workpiece-vice structure. From the experimental measurements the most important modes with their dynamic characteristics, i.e., natural frequency, half power frequencies, damping ratio, and magnitude

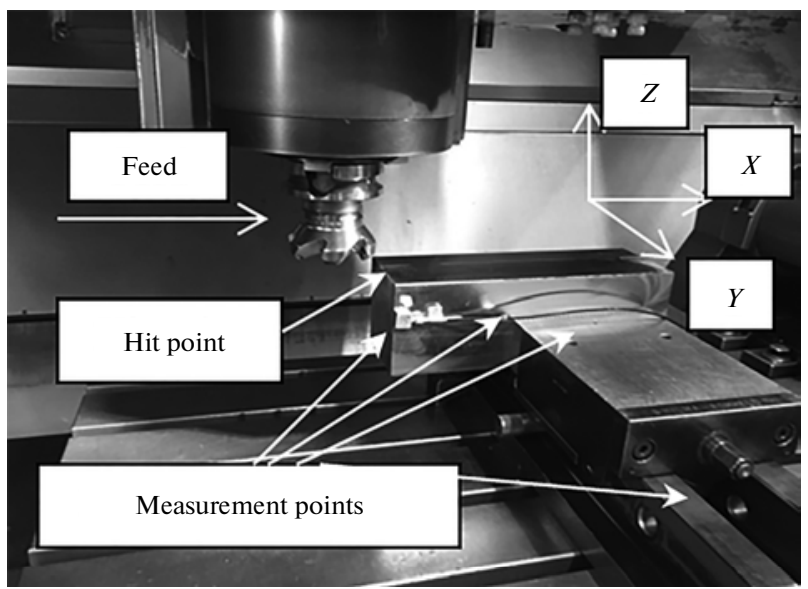

Fig. 7. Work piece - vice structure. 
have been extracted. The FRF (Frequency Response Function) has then been computed for each direction using the experimental data. The impact hammer tests have been carried out with high pass filter with cut off frequency of $200 \mathrm{~Hz}$. Consequently, the low frequency range and its influence on the FRF have been neglected in the modal analysis. The frequency response functions for each direction are shown in Fig. 8.
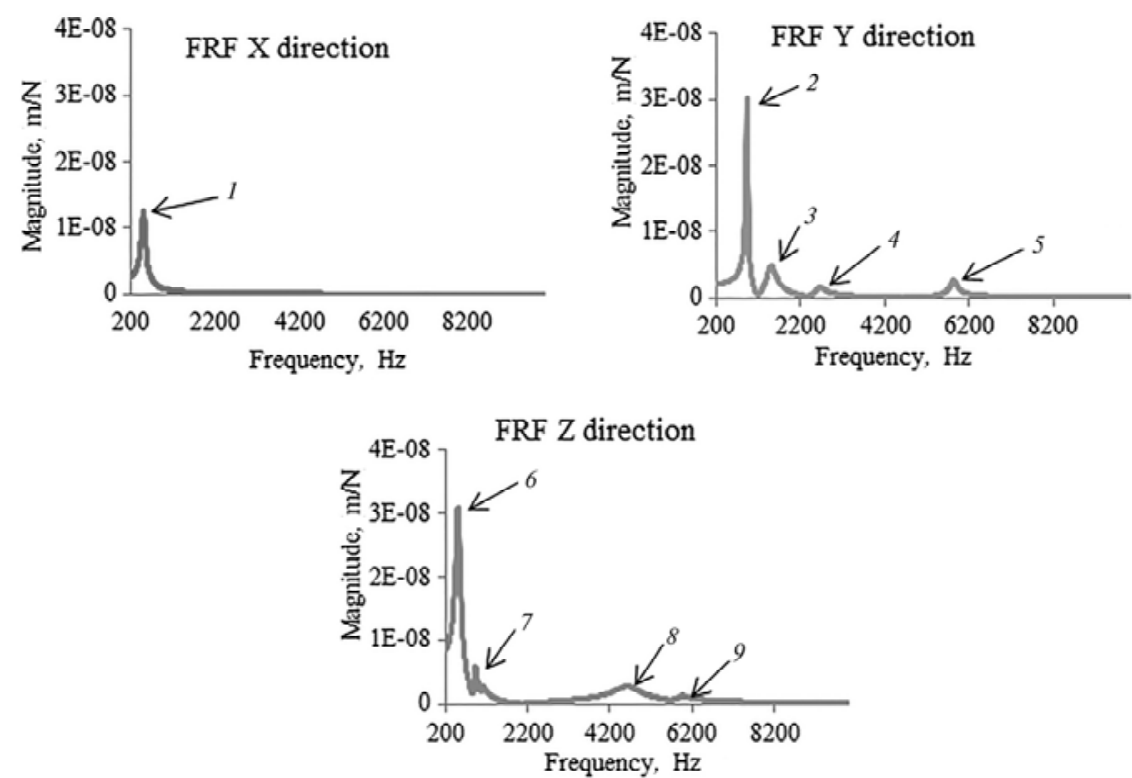

Fig. 8. FRF functions for $X$ (490 Hz (1)), $Y$ (920 (2), 1490 (3), 2600 (4), 5810 (5) Hz), and Z (500 (6), 920 (7), 4610 (8), $6000(9) \mathrm{Hz})$ directions.

Despite the rather stiff configuration of the structure, the first natural modes for all directions are below $1 \mathrm{kHz}$. The FRF functions seem to be strongly affected by the machine table, vice and clamping system. The $X$ direction is approximated with one dominant mode at $490 \mathrm{~Hz}$ which is close to the first natural mode in the $Z$ direction. The first mode in the $Y$ direction is at $920 \mathrm{~Hz}$ and in the $Z$ direction at $500 \mathrm{~Hz}$. These are the most flexible modes in the structure within the frequency range defined by high pass filter at $200 \mathrm{~Hz}$.

\section{Theoretical aspects}

One of the basic characteristics of the milling process is the chip thickness variation during the cutting. The entry and exit takes place at the different positions with different radial depth of cut and positioning of the milling cutter with respect to the workpiece. Consequently, the chip thickness also varies depending on the tool's positioning.

In addition, the geometrical properties of the milling tool as lead angle, helix angle, rake angle and protection chamfer have tremendous effect both on the magnitude and build-up process of the load. In the majority of the milling applications the cutting force is periodic and nonharmonic. This is despite the fact that the chip thickness is a function of a feed per tooth and engagement angle as shown in Eq. (1). The main reason for this behavior is the interruption of the cutting process that causes the ramp-up of the force at the entry and exit. This phenomenon causes broader frequency excitation range and is in general dealt by Fourier series, which 
results in number of harmonics necessary to sufficiently describe the dynamic force:

$$
F(t)=\frac{a_{0}}{2}+\sum_{n=1}^{\infty} a_{n} \cos n \omega t+\sum_{n=1}^{\infty} b_{n} \sin n \omega t .
$$

In the expression above $n$ is the harmonic of the fundamental frequency. The ramps created by the entry and exit of the force generate large number of harmonics carrying sufficient energy that correspond to the increase of the vibration amplitude. If any of harmonics coincides or is close to any of natural modes there might be risk of increasing the amplitude of vibration. Changing the RPM may resolve the issue as the fundamental frequency alters but it is not always an easy task especially if there are many significant natural modes close to each other. In order to capture the force build-up process it is necessary to include higher harmonics. This is exemplified in Fig. 9 where the force is modeled by different number of harmonics, $n$ equal to 4 and 30 .

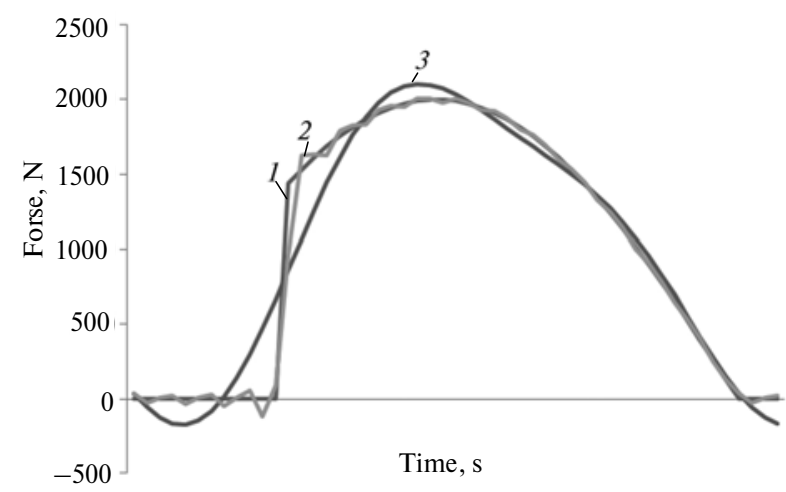

Fig. 9. Cutting force simulation by Fourier series: theoretical force (1), simulated force, $n=30$ (2), $n=4$ (3).

Although a sudden increase or decrease of the chip thickness causes an impact load on the cutting edge, the main parameters that influence the impact originate from the tool geometry, workpiece geometry, and cutting data. If the basic assumption is that the amplitude of the vibration is essential for the cutting process, then a method to evaluate the vibration amplitude of the milling process would be worthwhile. In this study, root mean square value, $R M S$, is utilized for the evaluation of the vibrations in the milling process. An advantage of this method is that it incorporates all vibrations that exist in the process. The forced vibrations, transient vibrations due to the entries and exits, potential chatter and regeneration effects are all incorporated in the evaluation of the total amplitudes using $R M S$ value. $R M S$ value can be expressed in the time domain as follows:

$$
R M S=\sqrt{\frac{1}{N} \sum_{n} y(n)^{2}},
$$

where $y$ is the amplitude and $N$ is the number of samples. In the frequency domain, $R M S$ can be computed using fast Fourier transform (FFT) coefficients, $Y(m)$ and number of samples $N$ as follows:

$$
R M S=\sqrt{\frac{1}{N^{2}} \sum_{m}|Y(m)|^{2}} .
$$


Ensuring that number of samples is constant for trials, the RMS values for different cutting situations can be used to quantify vibration amplitudes. There are several characteristics of this method that are advantageous. Firstly, the method gives one parameter that describes the dynamics of the cutting. Secondly, it captures the strong amplitude variations at the interruption of the cut, and finally it also gives a robust result as it is in this particular case computed over 14 engagements.

\section{RESULTS}

In order to analyze and explore all significant features from the measurement data, the results are presented both in time and frequency domains while the RMS values are presented and discussed in the end of this section.

\section{Time domain analysis}

The sampled acceleration data for all radial depths of cut and all three directions are shown in Fig. 10. It is important to emphasize that the scale is four
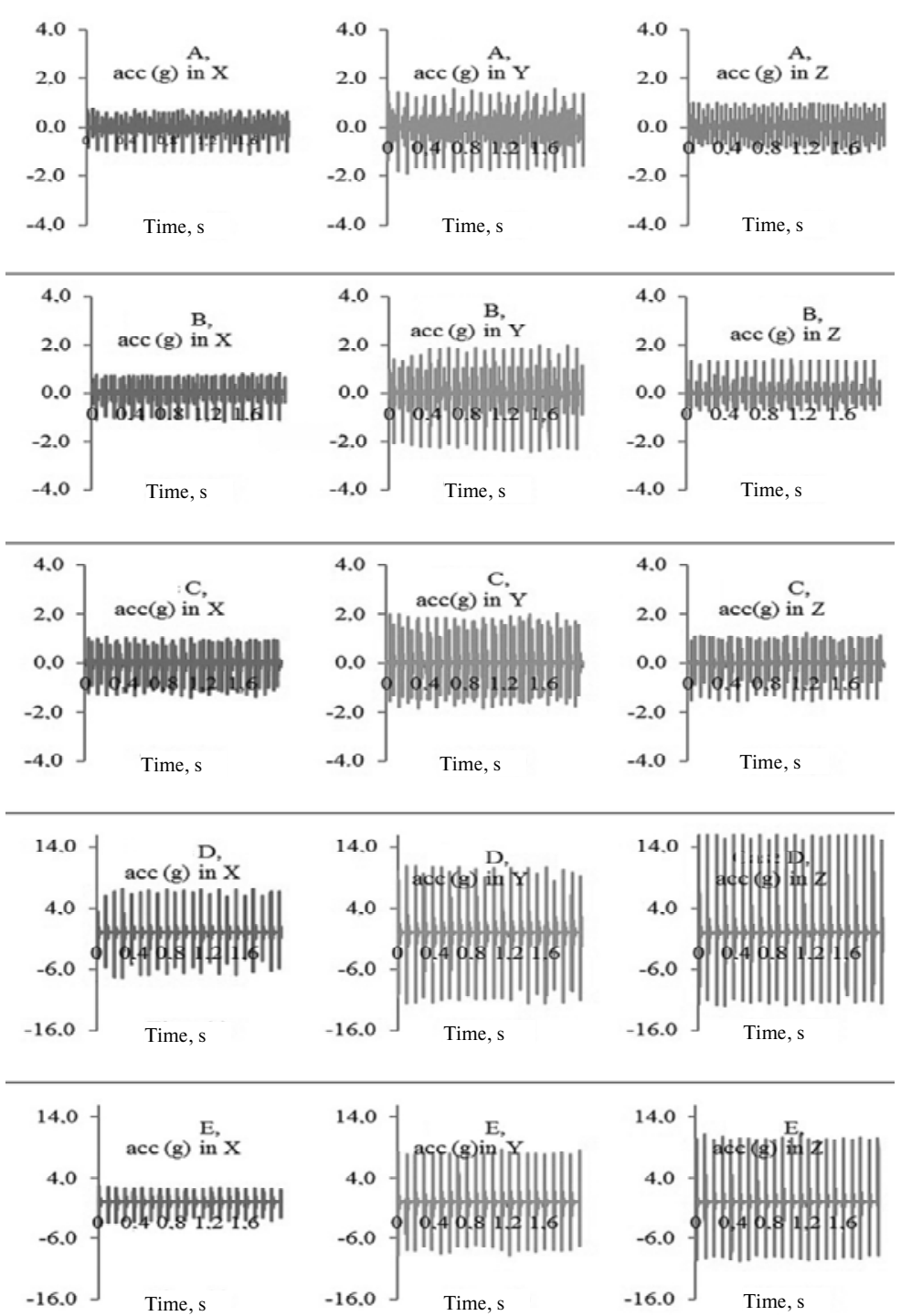

Fig. 10. Accelerations in $X, Y$ and $Z$ directions for CG1. 
times greater for the cases D and $\mathrm{E}$ than for other three radial depths of cut. It is due to the fact that the measured acceleration is significantly higher for these two cases compared to the rest, which is a consequence of sudden impact over the whole depth of cut. The magnitude of the acceleration of the workpiece seems to be strongly dependent on the impact force at the entry and exit of the cutting edge. It is assumed that the measured acceleration signal from the workpiece incorporates all types of vibrations: transient, forced, and regenerative vibrations. The milling processes for all applied cutting conditions in the trials are stable, i.e., there is no growth of the amplitudes over time which can be seen in the graphs in Fig. 10. As the peak of the acceleration amplitude for the case D is roughly $16 \mathrm{~g}$ compared against, for instance the case B, where the acceleration peak is $2 \mathrm{~g}$, it strongly indicates that the impact load has tremendous effect on the vibration behavior of the milling tool and the workpiece. In general, the acceleration measured on the workpiece in these trials demonstrates strong dependency upon the entry and exit loads.

As shown in Fig. 11, the distribution of the acceleration peaks over time seems to exhibit similar patterns for all radial positions. The highest peaks are generated at the entry but a significant increase of acceleration is evident at the exit too. This effect can be seen particularly in the cases A and B where the chip thickness is small at the entry of the cutting edge into the workpiece. The exit acceleration has higher amplitudes than the entry acceleration for the cases A and B, which is shown in Fig. 11. Looking at the magnitude of the peaks at the exit, they seem to be independent of the acceleration amplitudes at the entry for the given cutting conditions that is illustrated in Fig. 11. Although there is no clear distinction between the entry and exit vibrations for the case $\mathrm{E}$ where the engagement is the shortest it might be concluded that the exit vibrations don't significantly change the magnitude compared to the case $\mathrm{C}$ or $\mathrm{D}$.
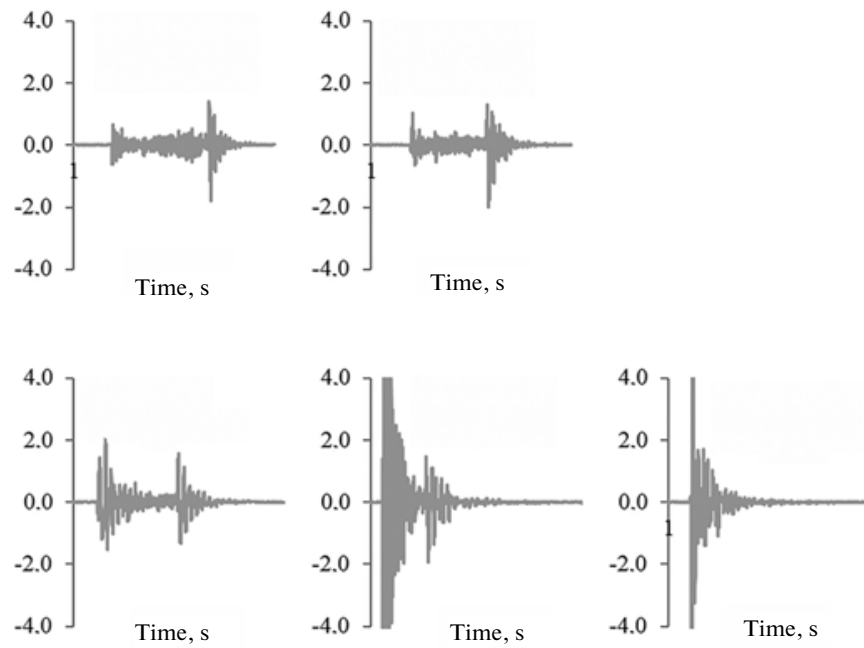

Fig. 11. Accelerations over one engagement in the $Y$ directions.

\section{Frequency domain analysis}

The sampled acceleration files are analyzed in the frequency domain using Fourier transforms. The algorithm for Fourier transform analysis is created in Mathcad. In order to reduce the effect of the leakage a Hanning window [6] is utilized in the algorithm. Looking at the frequency spectra for the different cases, there seem to be several major frequency components in the acceleration signals. In 
order to visualize the difference in the results for the given cutting conditions the same scale for the graphs is used. Several important observations can be made from the frequency spectra in Fig. 12. Firstly, the frequency spectra for the cases $\mathrm{A}, \mathrm{B}$, and $\mathrm{C}$ seem to be very similar. The strongest frequency components for A, B, and $\mathrm{C}$ cases in the $X$ direction come from low frequency range (defined here up to $200 \mathrm{~Hz}$ ) around $32 \mathrm{~Hz}$, which corresponds to the third harmonic of tooth passing frequency. Besides this frequency component, the next strongest frequency component in the $X$ direction is around $500 \mathrm{~Hz}$ which corresponds to the first mode in the $X$ direction. In the $Y$ direction the highest magnitudes are around the first mode in the $Y$ direction, $900 \mathrm{~Hz}$ but the second $(1517 \mathrm{~Hz})$ and the fourth $(5868 \mathrm{~Hz})$ modes have also certain contributions in the frequency spectrum. The low
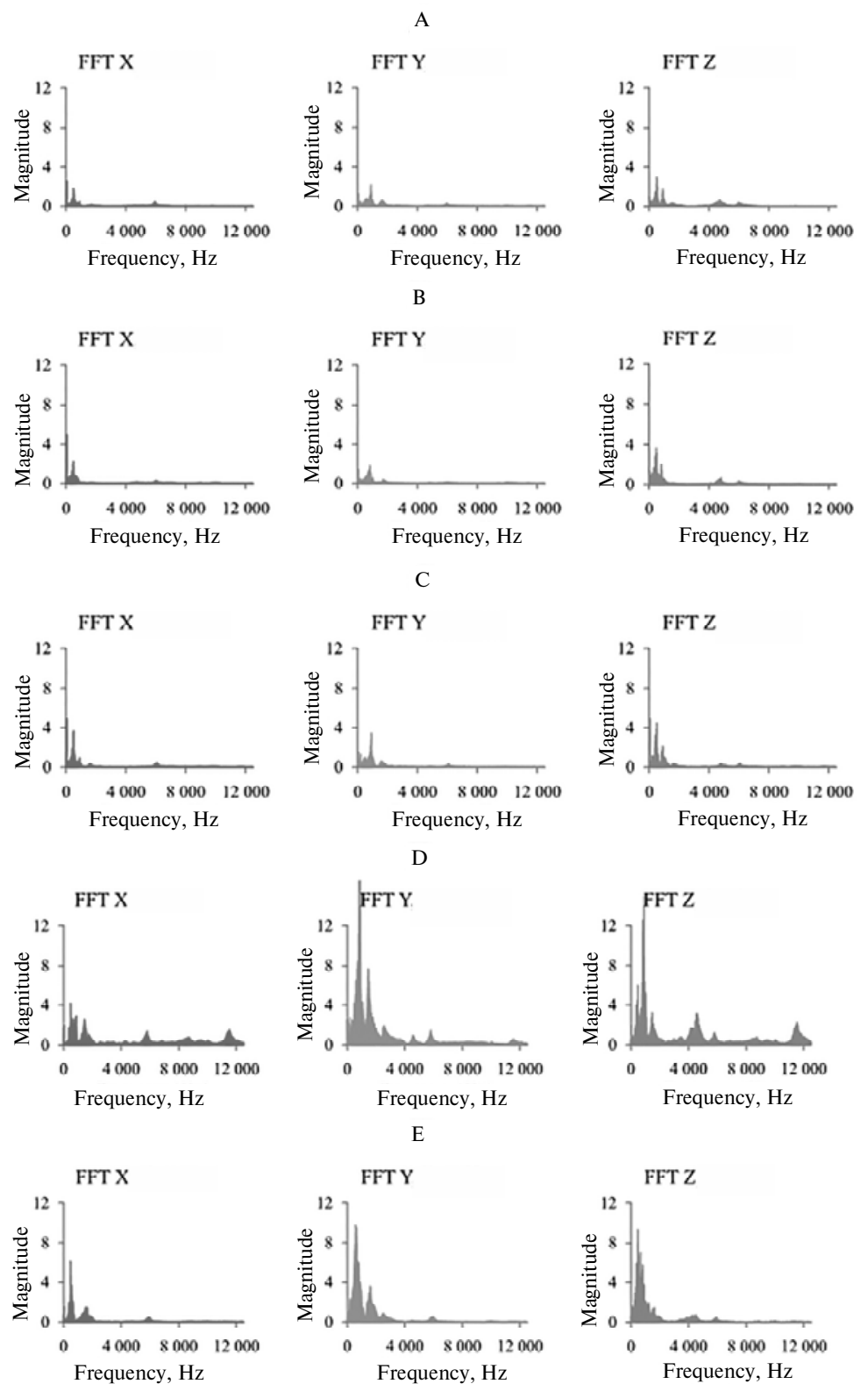

Fig. 12. Frequency spectra for CG1. 
frequency component at $32 \mathrm{~Hz}$ is strongly presented in the $Y$ direction too. For the frequency spectrum in the $Z$ direction the dominant modes are the most flexible modes (497, 917, and $1091 \mathrm{~Hz}$ ) but also some increase of the magnitude is notable at the third and fourth modes (4639 and $6099 \mathrm{~Hz}$ ). The significant contribution of the low frequency range can be found in the $Z$ direction. The greatest difference in the amplitudes is generated in the case $\mathrm{D}$. The frequency range excited at this cutting conditions is much bigger compared to the rest of the cutting conditions causing significant excitation even at high frequencies around $11500 \mathrm{~Hz}$. All lower modes seem to be strongly presented in the frequency content in the case $\mathrm{D}$ including the low frequency range. The last radial depth of cut, the case E shows the similar trend as for the case D. The magnitude of the peaks is lower compared to the case $\mathrm{D}$, while it is significantly higher compared against the rest. The frequency spectrum does not contain the highest frequency component $(11500 \mathrm{~Hz})$ as in the case D. The magnitude of the vibrations is highest in the $Y$ and $Z$ directions. The lowest level of the vibrations is in the $X$ direction. This behavior coincides well with the conclusion drawn from the modal analysis as the most flexible modes are in the $Y$ and $Z$ directions. Additionally, the cutting force direction as the source of the excitation in the relation to the workpiece has great impact on the magnitude of the vibrations.

\section{Root mean square, $R M S$}

From the sampled acceleration files, $R M S$ values have been calculated for all five cutting conditions.

RMS and radial depth of cut. RMS has been computed directly from the sampled data in the time domain. The computed RMS values exhibit strong dependency on the radial depth of cut. The trend seems to be identical for all three directions. The RMS values for the critical radial depth of cut, the case $\mathrm{D}$ are roughly three to five times higher compared to the other radial depths of cut. All cutting geometries show the same trend as illustrated in Fig. 13.
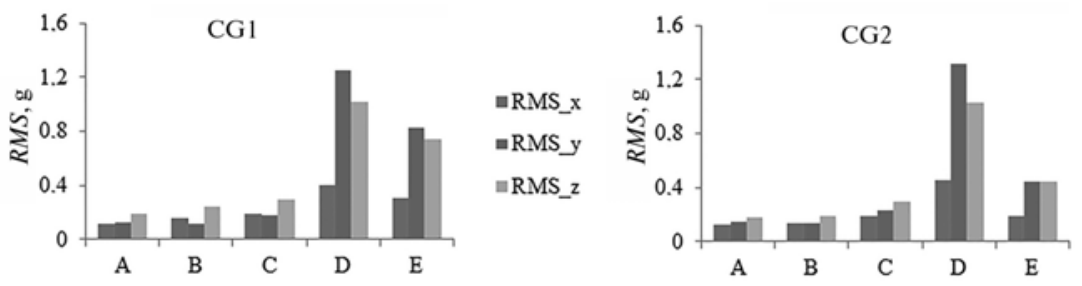

-RMS_x

=RMS_y

$=$ RMS_z

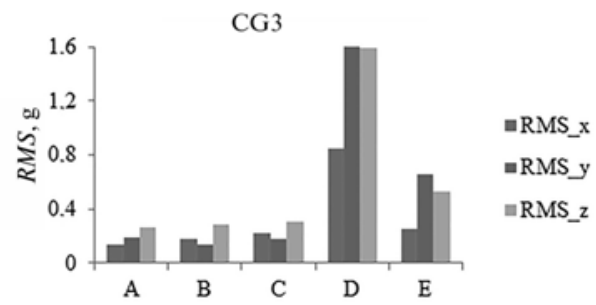

Fig. 13. RMS as function of radial position for different cutting geometries.

As the radial positions B-E and D-C are symmetrical with respect to the central axis of the milling cutter, the chip thickness is assumed to be equal at the very entry of the cutting edge into the workpiece. The difference in the entry position is that the chip thickness grows in the up-milling case (B and $\mathrm{C}$ at the entry) while it 
decreases in the cases D and E. Despite the growth of the chip thickness for the B and $\mathrm{C}$ cases the RMS values are higher for the critical case $\mathrm{D}$ where the entry is momentous but even for the case $\mathrm{E}$ in comparison to the case $\mathrm{B}$. The acceleration graphs demonstrate stable cutting conditions as there is no significant increase of the acceleration amplitudes over time. Although the regeneration effect might be present in these particular cutting conditions its effect seems to be suppressed by the transient and forced vibrations. In order to further explore the influence of the radial depth of cut and entry conditions on the vibratory behavior in milling an additional test has been carried out by fully equipped milling cutter. The milling cutter had differential pitch and 6 inserts with the cutting geometry CG3. Interestingly, as shown in Fig. 14 the vibrations generated on the workpiece with fully equipped cutter seem to give very similar dependency of $R M S$ value as the trials run with one tooth.

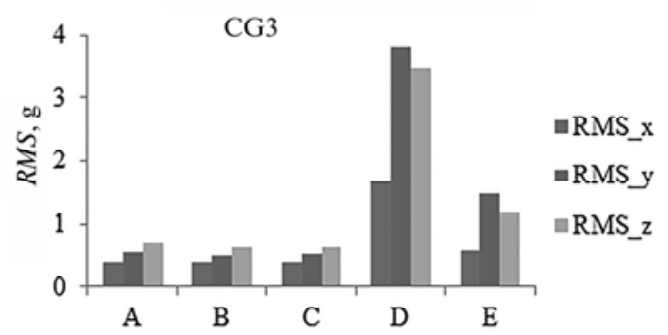

Fig. 14. RMS as function of radial position for $z=6$.

RMS and cutting geometries. Three cutting geometries, CG1, CG2, and CG3 have been run in identical cutting conditions as shown in Table 1. RMS values from these tests are shown in Fig. 15.

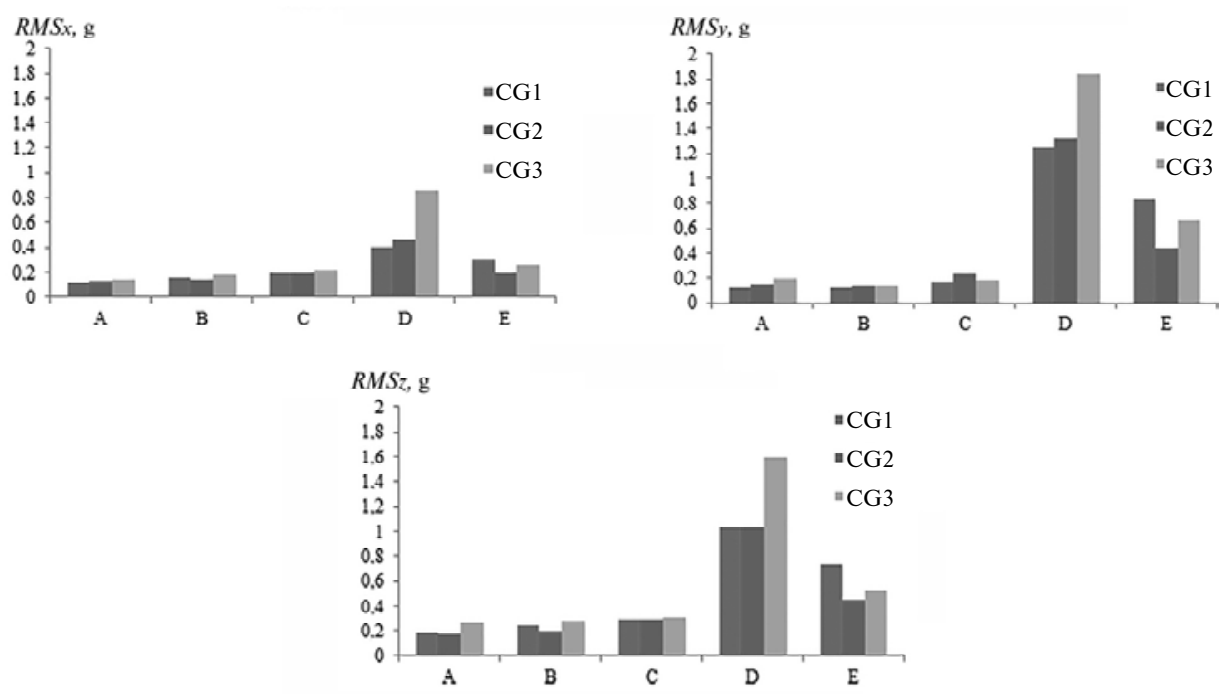

Fig. 15. RMS in $X, Y$, and $Z$ as function of cutting geometry.

Even if there seems to be certain pattern in the graphs for the case $\mathrm{D}$ and $\mathrm{E}$, the relations between the vibration amplitudes and cutting geometries is not completely clear. For instance, the most negative geometry, both on the rake angle and chamfer angle generates highest vibrations in the case $\mathrm{D}$, but not on the case $\mathrm{E}$. It 
can also be observed that CG2 which is most positive geometry gives higher vibration than CG1 in the case D. It should be emphasized at this stage that the cutting edge of CG3 is straight line, while it is curved line in the case of CG1 and CG2, which has strong impact on the entry vibrations. Despite that, in some cutting conditions CG1 and CG2 give higher amplitudes compared to CG3. Although the chip thickness is assumed to be identical at the very entry for B-E cases and C-D cases, the geometrical conditions are different, including the contact point and chip growth. Even potential damping effects as function of cutting geometry might affect $R M S$ value.

\section{ANALYSIS OF RESULTS}

The results shown in the previous section indicate that the entry of the cutting edge into the workpiece has significant effect on total level of vibration of milling cutter. The entry of the cutting edge might be characterized by two important parameters, the magnitude and rise time of the impact. These parameters directly depend on geometrical features of the tool and workpiece but also process conditions as cutting parameters. If we assume that a certain load variation, i.e., its amplitude has negative effect on the tool life, for instance causing chipping, sudden failure or any other effect that originates from the load variation on the cutting edge, then the entry but also exit condition play important role not only on dynamics but whole mechanics of the cutting. Although the given cutting condition generates stable cutting, the importance of the reduction of the amplitude of vibration might be essential for the tool life.

The cutting force that is generated by the impact, which is also the driver of the acceleration of the structure, is periodic and nonharmonic. This force with its frequency content excites the structure. Resulting motion of the structure is affected by each harmonic of the cutting force but also the modal properties of the structure. Looking at the results in the frequency domain, a number of dominant frequencies can be found. These frequencies coincide rather well with the natural modes presented in the modal analysis; which indicates that the harmonics of the cutting force strongly affect the vibration amplitude. For the case D when the radial depth of cut is critical, not only the magnitude of the vibration is higher but the frequency range that is excited in this case is much higher showing the significant amplitudes even at 8.7 and $11.4 \mathrm{kHz}$.

The proposed method by utilizing direct RMS approach on the measurements of the acceleration of the workpiece seems to give rather precise description of the dynamics in the different cutting conditions. This method emphasizes the amplitude and its variation over the engagements. It also demonstrates unfavorable radial depth of cut, i.e., entry conditions quite easily. Another advantage of the $R M S$ value is that it possesses statistical value as it is directly related to variance. Changing of the radial depth of cut changes both the magnitude and the rise time of the impact. The unfavorable radial depth of cut can be identified from the computed RMS value. It is important to emphasize that $R M S$ gives a measure of the vibration amplitude over time and doesn't quantify any other parameter that might affect the tool life.

As already stated, the milling tests in this study have all been stable. Taking that into account, it might be of interest to look into the result when the cutter was fully equipped. Despite the fact that the number of teeth in the engagement is greater for $\mathrm{A}, \mathrm{B}$, and $\mathrm{C}$ cases compared to the critical (D) radial depth of cut, computed RMS value is higher for $\mathrm{D}$ case which highlights the effect of the entries and exits on the vibrating behavior of a milling cutter. 
Additional work seems to be required to further explore the influence of the cutting edge geometry on the milling dynamics.

\section{CONCLUSIONS}

Root mean square value captures the relation between the entry of the cutting edge into workpiece and vibrations in milling.

The presented method can be utilized for the evaluation of tools and optimization of cutting conditions.

There is no consistent relation between the vibration amplitudes and cutting geometries. The results indicate that the choice of the cutting geometry to minimize vibration might also be the function of the radial depth of cut.

This paper presents the results of a joint work between Seco Tools AB and University West in Sweden. Funding of the project, provided by Seco Tools and the KK foundation, is highly appreciated. Support from The Research School of Simulation and Control of Material affecting Processes (SiCoMaP) is also gratefully acknowledged.

Вибір геометрії фрези і відповідних режимах різання за певних умов фрезерування має важливе значення для успішної обробки. Несприятливий вибір режимів різання може призвести до виникнення високих навантажень, які викликають серйозні пошкодження ріжучої кромки фрези. Радіальна глибина різання в поєднанні з геометрією ріжучої фрези можуть при деяких обставинах створювати несприятливі умови стосовно сил різання і амплітуди коливань. Це явище залежить від геометричні параметрів фрези, які впливають на збільшення часу врізання ії ріжучої кромки в оброблювану деталь при різних радіальних глибинах різання. Оскільки радіальна глибина різання часто є суттєвим параметром, зокрема при фрезеруванні матеріалів, щьо важко обробляти різанням, важливо дослідити механізм виникнення вібрації. У даному дослідженні прискорення оброблюваної деталі вимірювали для різних радіальних глибин різання і геометрії ріжучої кромки фрези. Вплив радіальної глибини різання на динамічну поведінку очінювали в часових $i$ частотних інтервалах. Отримано кількісні результати для різних радіальних глибин $i$ геометрії різання з використанням середньоквадратичного значення прискорення. Результати иььго дослідження можуть бути використані для рекомендачій як покращення процесу різання, так і конструкиії інструменту.

Ключові слова: фрезерування, радіальна глибина різання, ріжуча кромка, сила різання, врізання, вібрація.

Выбор геометрии фрезы и соответствующих режимов резания при определенных условиях фрезерования имеет важное значение для успешной обработки. Неблагоприятный выбор условий резания может привести к высоким нагрузкам, вызваюшим серьезные повреждения режущей кромки фрезы. Радиальная глубина резания в сочетании с геометрией фрезы при некоторых обстоятельствах могут создавать неблагоприятные условия относительно сил резания и амплитуд колебаний. Это явление зависит от геометрических параметров фрезы, которые влияют на время врезания ее режущей кромки в заготовку при разных радиальных глубинах резания. Поскольку радиальная глубина резания часто является существенным параметром, особенно при фрезеровании материалов, труднообрабатываемых резанием, важно изучить механизм возникновения вибрации. В данном исследовании ускорение перемещения заготовки измеряли для разных радиальных глубин резания и геометрии режущей кромки фрезы. Влияние радиальной глубины резания на динамическое поведение оценивали во временных и частотных интервалах. Получены количественные результаты для различных радиальных глубин и геометрии резания с использованием среднеквадратичного значения ускорения. Результать этого исследования могут быть использованы для рекомендаций по улучшению как проиесса резания, так конструкиии инструмента.

Ключевые слова: фрезерование, радиальная глубина резания, режущая кромка, сила резания, врезание, вибрачия. 
1. Altintas Y. Analytical prediction of three dimensional chatter stability in milling // JSME Int. J. Ser. C. - 2001. - 44, N 3. - P. 717-723.

2. Budak E. An analytical design method for milling cutters with nonconstant pitch to increase stability, Part I: Theory // J. Manuf. Sci. Eng. - 2003. - 125, N 1. - P. 29-34.

3. Diniz A. E., Filho J. C. Influence of the relative positions of tool and workpiece on tool life, tool wear and surface finish in the face milling process // Wear. - 1999. - 232, N 1. - P. 6775.

4. Ståhl J.-E. , Andersson M. , Bushlya V. et al. Metal Cutting: Theories and Models. - Lund, Sweden: Lund University Press, 2012. -580 p.

5. Kuljanic E., Sortino M., Totis G. Multisensor approaches for chatter detection in milling // J. Sound Vib. - 2008. - 312, N 4-5. - P. 672-693.

6. Brandt A. Noise and Vibration Analysis: Signal Analysis and Experimental Procedures. - John Wiley \& Sons, 2011. - 466 p.

Received 06.03.17 